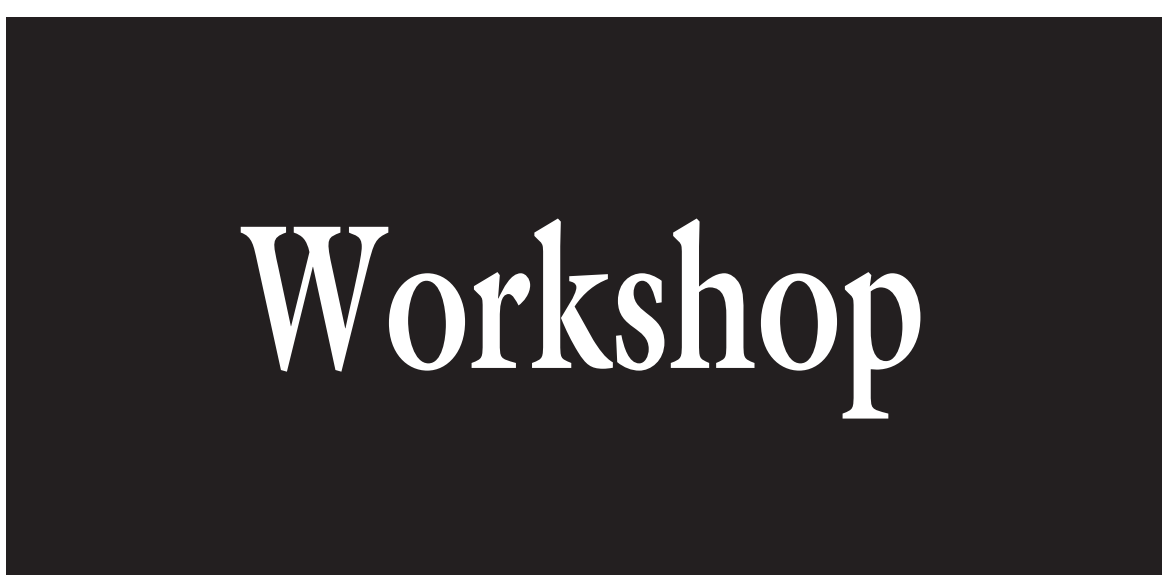

\title{
Making Cents of Green Industry Economics
}

\author{
Charles R. Hall ${ }^{1,2}$
}

\section{AdDitional INDEX WORDs. downturn, recession, recovery}

$\overline{\text { SUMMARY. The green industry complex includes input suppliers (manufacturers and }}$ distributors); production firms such as nursery, greenhouse, and sod growers; wholesale distribution firms including importers, brokers, re-wholesalers, and transporters; horticultural service firms providing landscape and urban forestry services such as design, installation, and maintenance; and retail operations including independent garden centers, florists, home improvement centers, and lawn/garden departments at home centers, mass merchandisers, or other chain stores. Many current economic trends and driving forces point to the fact that the green industry is in a period of hypercompetitive rivalry due to the maturing consumer demand. A number of firms have already been forced out of the green industry during the 2008-09 recessionary shakeout period and others continue to exit. To address this issue, a workshop was organized by G. Zinati for the 2009 ASHS annual meeting entitled "Managing and Thriving in Tough Times, When Every Dime Counts!", which was sponsored by the Nursery Crops (NUR) and Marketing and Economics (MKEC) Working Groups and the American Nursery and Landscape Association (ANLA). This lead-off workshop presentation: 1) provided an overview of current economic conditions and trends and their influence on the green industry, 2) discussed supply-side methods and technologies for controlling costs during an economic downturn, and 3 ) addressed proactive demand-side differentiation and pricing strategies that will not only help ensure survival, but will also better position green industry firms for competing profitably in this period of hypercompetition.

$\mathrm{T}$ wo widely held beliefs prevail among economists regarding recoveries: deep recessions usually lead to strong recoveries and financial crises usually produce weak recoveries (Balke and Wynne, 1995). But the curious thing about the "Great Recession" (as some have referred to the 2008-09 recession) is that it has been a deep recession kick-started by a financial crisis and fostered by a sundry of asset bubble bursts. The interplay of

$\overline{\text { Texas A\&M University, } 2133 \text { TAMU, } 201 \text { Horticul- }}$ ture/Forest Science Building, College Station, TX 77843-2133

${ }^{1}$ Professor and Holder of the Ellison Chair in International Floriculture.

${ }^{2}$ Corresponding author. E-mail: charliehall@tamu.edu. particularly severe in the volatile multifamily housing sector, but even the single family housing market was negatively impacted. But, as usual, there is the preverbal silver lining: while this is not good for gross domestic product (GDP), it is good for the long term re-balancing between housing supply and demand that needs to take place to prevent another housing bubble (Shiller, 2005).

On the demand front, the homebuyer tax credit was extended after all and even expanded. The Federal Reserve's policy of low interest rates is keeping financing costs down within the mortgage market and improving affordability in many markets and, thanks to the decline in prices, buyers are slowly responding to these incentives. More than likely, the industry will continue to see a slow, steady recovery in existing and new home sales, a continued gradual decline in the number of homes on the market, a tepid rebound in home construction, and broad-based stabilization in home prices as we head into 2010. Again, a slow but steady pattern of growth is expected, with some market disturbances along the way. All of the statistical data on housing makes sense if considered from that viewpoint (Macroeconomic Advisers, 2009).

The good news overall is that the nation's primary indicator of economic productivity, the GDP, grew in the third quarter by $2.8 \%$ and by $5.7 \%$ in the fourth quarter of 2009 , unofficially ending the recession (Congressional Budget Office, 2008, 2009). The manufacturing sector is seeing signs of shrinking inventories and manufacturers are showing a willingness to replenish these low supplies in anticipation of a broader-based recovery (U.S. Census Bureau, 2009). But we (as a country) still have tremendous hurdles to face and in some ways we have cross-subsidized various industries to attain the productivity gains we have realized thus far (e.g., American Recovery and Reinvestment Act of 2009, Consumer Assistance to Recycle and Save Program, Targeted Asset Relief Program, etc.). Remember the old adage about no free lunchsooner or later we will have to pay for all the government stimulus-induced infrastructure spending we have put in place to boost spending and productivity. However, some of that stimulus money that remains unspent is for 
green infrastructure-related projects, which may translate into potential market niches for the green industry.

While inflation has not been a major factor yet (to the surprise of some), at some point the Federal Reserve will be talking about fiscal and monetary policy measures to curb inflationary pressures. But in the very short run, we can expect to see even more targeted stimuli come out of Congress, but in smaller pieces (to not draw attention to the deficit spending), and with an even greater focus on job creation. To that end, the Federal Reserve will likely hold interest rates at a level that will encourage business-level investment as much as possible (The Conference Board, 2009a), and much of this may be related to bolstering green infrastructure which, again, may indirectly increase the demand for green industry products and services (e.g., green roofs, carbon offsets, etc.).

Another curious feature of this recovery is continued above-normal unemployment, prompting some to name this a jobless recovery (an oxymoron, but the point is made). Cautious hiring practices of businesses continue to cast a shadow over the outlook for $\mathrm{V}$-shaped economic growth (thus my earlier comment about the shape of this recovery cycle). Of course, these cautious hiring practices have a positive and negative dimension. On the one hand, they are generating exceptionally strong gains in productivity, which strengthens profits and provides the financial wherewithal for business investment in new equipment. On the other hand, it also undermines consumer confidence and further reduces household incomes that are needed to support spending.

Interestingly, the U.S. Department of Labor reports that the number of occupational injuries and illnesses that required days away from work mirrored the shifts the recession caused in the labor market in 2008-09 (U.S. Department of Labor, 2009). Hardhit sectors such as construction and retail reported fewer injury and illness cases. Older workers experienced more injuries as their labor force participation rose, but incidents among younger (normally more risk-seeking) workers fell counter-intuitively, mainly because fewer of them remained employed.

The other positive externality of the increased unemployment is that green industry firms have benefited to a certain extent from the availability of more bodies in the available workforce, but this has pushed back serious discussions of needed immigration reform in Congress. In the interim, we will likely see more emphasis on enforcement (rather than policy change), resulting in an increase in auditing of businesses across the United States.

While businesses responded to the recession by cutting back their work forces, eventually they will have to begin hiring to increase output. That time may not be too far offthere is at least some evidence pointing in that direction already. Wage rates will stabilize for a while, but at slightly suppressed levels. In the end, we should expect to see job growth return in the late Spring or Summer 2010 , albeit a slow growth and the technology industry will likely lead this recovery.

In Spring 2009, sales of bedding plants and perennials fared well in the green industry and expectations are the same for this upcoming spring, providing the weather holds, of course (Deschênes and Greenstone, 2007). The country is much better off economically than it was last year at this time, and consumer confidence indices are nearly twice the levels we saw then (The Conference Board, 2009b). The question is how the Great Recession has impacted long-term spending habits of post-Great Recession consumers.

\section{Long-term consumer behavior}

One unexpected externality is that the recession has caused many young adults to move back home, according to a study released by the Pew Research Center (2008). Through mid-2009, households had lost $\$ 12$ trillion, or $19 \%$ of their wealth, because of the collapse in housing and stock prices (National Association of Realtors, 2009). That has reduced their purchasing power and pushed them to save more, especially those nearing retirement. Though they will boost their saving gradually, it still means consumer spending (which comprises about $70 \%$ of GDP) will grow more slowly than income, after two decades in which it usually grew more quickly. Leaving aside swings in energy prices, inflation (now about $1.5 \%$ ) will slip to zero and may turn to deflation in late 2010. Deflation occurs when the inflation rate falls below zero, which drives up real debt burdens, further sapping consumer spending.

But the real question is whether the newfound frugality on the part of post-Great Recession consumers is a permanent behavioral shift or will a new age of affluence emerge? Pundits differ on this question and there have been compelling arguments for both sides (Muellbauer, 2007). My own opinion is that there will be a slow return to normalcy in which people will abandon the exuberance of the boom, but without going overboard into miserliness. However, some market analysts are looking for a return to Great Depression-like attitudes toward thrift. However, a closer look at this phenomenon disrupts this premise.

As logic would dictate, the savings rate during the Great Depression was fairly low because with incomes down (or nonexistent), people could not afford the luxury of saving. It was not until World War II that the savings rate increased dramatically due to rationing and price controls (goods were not available for purchase), which continued through mid-1946. During the early post-war years, the savings rate again was low, as consumers used their accumulated savings to buy newly available consumer goods. The savings rate reversed trend and increased again during the 1950s, 1960s, and 1970s. During the 1980s, 1990s, and 2000s, we saw the savings rate reverse trend again and decline significantly. Why? Perhaps a more reliable social safety net reduced the need for savings, or perhaps social attitudes toward nearterm satisfaction versus long-term risk were changing. However, it certainly was not demographic change. The Baby Boomers were advancing into their high-earning years, which are typically high savings years, so the savings rate should have risen. Some argued that our savings rate got so low because people assumed that their home value appreciation would do their savings for them. However, the savings rate declined steadily through the 1990s, when home price appreciation averaged only $3 \%$ per year.

Bear in mind that the officially calculated savings rate undercounts investment income, thereby underestimating savings. Nonetheless, consumers may well return to a higher savings rate. However, there is no justification for them moving their savings rate up any faster than they 
moved it down. Aside from the World War II experience, sharp moves tended not to last. The big changes were/are gradual ones. The point and the big lesson in all this is that consumers can raise their savings rate without going into permanent frugality. They will likely still grow their spending, just at a slightly slower pace. That is positive for the economic outlook because we need consumer demand in the near term to help the economy recover. This means that retailers should monitor their sales very closely, not only in the aggregate, but also by price point.

\section{Quality of life as an industry message}

Two not-so-well-known, but insightful, economic principles also have bearing on this matter and can be summarized as follows: 1) expenditures rise to meet income (Parkinson, 1957) and 2) people afford what they want (Catlett, 2009). The job of the green industry (growers, service providers, and retailers alike) is to make sure they are providing \#2 in such a way that they capture their fair share of \#1. Stated slightly differently, if the green industry can position itself in such a way that its products/services are considered as necessities in people's lives and not mere luxuries, that is the best recession proofing and weather proofing it can do.

This last point warrants further examination. The value proposition for the green industry in the future must focus on the unique ways in which quality of life is improved for its customer base. Much research has validated the emotional and environmental benefits of flowers, plants, and trees. In general, these studies have demonstrated that green industry products and services improve emotional health, boost seniors' well being, enhance hospital recovery rates, enhance employee innovation and ideas, strengthen feelings of compassion, decrease worry and anxiety, express feelings of compassion, build stronger communities, mitigate environmental externalities, and improve the economic value of homes-just to name a few of the benefits (America in Bloom, 2009).

The green industry cannot overemphasize the importance of this quality of life message, particularly in focusing its differentiation strategies in the future. Whether one is a member of the Baby Boomer, Gen X, or Gen Y generation, quality of life is a "higher order" need that is important to them. For example, although the economic downturn has increased anxiety on the part of Baby Boomers about retirement, they are nevertheless proactive in seeking innovative solutions to dealing with aging. They view their new stage of life as one of activity and fulfillment rather than idleness. Gen $\mathrm{X}$ is the most "time-starved" generation, often juggling career and family obligations, but they maintain a strong commitment to work-life balance in their lives. The Gen Y generation is just beginning their adult lives and facing lots of firsts: their first home, first job, and most importantly, first independent income. They are trying to find the right balance between spending for necessities and spending for entertainment. This generation is concerned not just with function and utility but also with style.

All of these generational attitudes come down to one thing: enhancing the quality of their lives through emotional well-being, ecosystems services benefits (also referred to as environmental amenities), and economic paybacks. Research shows that there is no better way to do this than through the daily use and/or enjoyment of flowers, plants, and trees. All the green industry has to do now is convince consumers of this in a manner that they view their products and services as necessities instead of luxuries. This will, of course, make the industry even more recession resistant in the future.

\section{The role of ecosystems services}

After a decade or more of discussions, a cap-and-trade policy to limit greenhouse gas (GHG) emissions was passed by the House last summer; a sweeping climate change bill known as Waxman-Markey, or officially the American Clean Energy and Security Act of 2009 (ACES). The "cap" part of the policy sets a hard limit on total carbon dioxide $\left(\mathrm{CO}_{2}\right)$ pollution, giving certainty to emission reduction over the years 2012-50. The cap gets tighter and tighter over time, reducing emissions gradually. Meanwhile, the "trade" part of the policy allows firms to trade permits that allow the holder to emit carbon dioxide. The initial allocation of permits does create winners and losers, so this allocation is a key policy choice (Intergovernmental Panel on Climate Change, 2007). One option is for the government to auction the permits so that the revenue can be used to implement tax cuts or to compensate those who lose. The other option is to give away permits to companies. This free allocation to past polluters is called "grandfathering."

The Senate had delayed any discussions over its version of a GHG bill until Spring 2010, but given the attention that has been placed on health care reform, it may be delayed even further. Regardless of when or how soon climate change policies are addressed, as greater emphasis is being placed on rehabilitating the environment and combating global climate change, the green industry is uniquely positioned to offer low-cost, effective solutions to achieving many of these far-reaching goals. Though it is widely recognized that landscape trees and plants enhance property values and make human environments more livable, we must remind policymakers that the plant materials we produce, distribute, retail, and install provide measurable and lasting environmental benefits. Trees, shrubs, and flowers sequester carbon, reduce energy use, mitigate water runoff, and clean the air. These ecosystem services, for trees especially, have been quantified by government and university researchers in hard dollars. By promoting the full array of services and benefits provided by trees and plants in the managed landscape, the green industry can redefine its products and services as aesthetic, economic, and environmental assets that increase in value over time.

\section{Literature cited}

America in Bloom. 2009. Benefits of plants: Economic. 26 June 2009. <http://americainbloom.org/resources/ Benefits-of-Plants-Economic.aspx $>$.

Auerbach, A.J. and W.G. Gale. 2009. The economic crisis and the fiscal crisis: 2009 and beyond, an update. Working Paper, Brookings Institution, Washington, DC/ University of California, Berkeley.

Balke, N. and M. Wynne. 1995. Are deep recessions followed by strong recoveries? Results for the G-7 countries. Res. Dept. Working Paper. Federal Reserve Bank of Dallas, Dallas, TX. 
Catlett, L. 2009. The economy: It's not that bad. 26 June 2009. <http://totalaccess.supermarketnews.com/2009/06/ 07/the-economy-its-not-that-bad/>.

Congressional Budget Office. 2008. The outlook for housing starts, 2009 to 2012. Congressional Budget Office, Washington, DC.

Congressional Budget Office. 2009. The budget and economic outlook: Fiscal years 2009 to 2019. Congressional Budget Office, Washington, DC.

Deschênes, O. and M. Greenstone. 2007. The economic impacts of climate change: Evidence from agricultural output and random fluctuations in weather. Amer. Econ. Rev. 97:354-385.

Intergovernmental Panel on Climate Change. 2007. Policies, instruments, and co-operative arrangements, p. 745-796. In: Climate change 2007: Mitigation of climate change. Contribution of Working Group III to the fourth assessment report of the Intergovernmental Panel on Climate Change. Cambridge University Press, Cambridge, MA.

Macroeconomic Advisers. 2009. The trough in housing starts: Are we there yet? Macro Focus 4:1-9.

Muellbauer, J.N. 2007. Housing, credit and consumer expenditures, p. 267-334. In: Housing, housing finance, and monetary policy. Federal Reserve Bank of Kansas City, Kansas City, KS.

National Association of Realtors. 2009. Housing and economic statistics (monthly releases). 26 June 2009. <http://www. realtor.org/research/research/reports statistics $>$.

Parkinson, C.N. 1957. Parkinson's law, and other studies in administration. Houghton Mifflin, Boston.

Pew Research Center. 2008. Psychology of bad times fueling consumer cutbacks.
26 June 2009. <http://people-press.org/ report/475/economic-worries-mount $>$.

Shiller, R.J. 2005. Irrational exuberance, 2nd ed. Princeton University Press, Princeton, NJ.

The Conference Board. 2009a. Leading economic index. 26 June 2009. <http:// www.conference-board.org/economics/ bci/press_archive.cfm? cid=l $>$.

The Conference Board. 2009b. Consumer confidence index. 26 June 2009. <http://www.conference-board.org/ economics/ConsumerConfidence.cfm $>$.

U.S. Census Bureau. 2009. Economic indicators. 26 June 2009. <http:// www.census.gov/cgi-bin/briefroom/ BriefRm>.

U.S. Department of Labor. 2009. Workplace statistics. 26 June 2009. <http:/ /www. dol.gov/dol/stats.htm>. 